\title{
VALUE ORIENTATIONS OF ADOLESCENTS AND YOUTH: REVIEW AND CURRENT SITUATION
}

\begin{abstract}
This article reviews a number of theoretical and scientific approaches in respect to specifics of value orientation formation and manifestation in adolescents and youth. The study of value orientations was carried out by review of the scientific positions on describing the process of values formation in ontogenesis, the need of implication in different human activities for development of value orientation in childhood, the impact of the broad range of factors that shape the value orientations, the correlation of values with structural elements of the personality etc. The experimental study initially undertaken in 2015 and repeated in 2019 reflects the specifics of the value orientations dynamics in adolescents and young people within the pre-university and university levels of education system. The content shows up-to-date nature of the research and outlines prospects for further priority in investigative area.
\end{abstract}

Keywords: value, value orientation, adolescents, youth.

\section{Introduction}

A gradual economic, social, spiritual, etc., transformation is taking place in society, which is expressed through changes in society and in the human being. Therefore, such modification is noticeable in disappearance of some values, significant for a certain period, and emergence of others. This transformation, from another perspective, has a beneficial impact on the progress of society and human being development, initiating the emergence of new value paradigms. The emergence of new values is always contradictory, and only in such contradiction one can find positive dynamics in the development of the postmodern society. 
The impact of new value paradigms on human beings is more forceful during the period of intense formation of the personality system, starting from 14 to 15 years and up to the age 22 to 25 . This age period is the time of study, when the personality potential is reached, when different capacities of the personality are manifested; the value system of the human being is established due to active socialization process. This period of person development needs to be monitored and studied in order to determine the specifics of the formation of value orientation and the nature of correlation with various elements within the personality system; to establish the type of relation with the environment through behavioral, attitudinal and cognitive manifestations.

\section{Theoretical-scientific approach}

The review of the scientific literature allows to highlight multiple approaches with regard to age periodization from various perspectives of personality development: psychosexual (S. Freud), psychosocial identification of the Ego (E. Erikson), cognitive as the basis of psychic life (J. Piaget, L. Vygotsky), psychic development determined by practical activity (D. Elkonin), Ego formation (G. Allport) etc. Thus, we can state, that each of these scientific positions on development of child's personality reflects in different ways the specifics of the formation of values in children.

According to S. Freud, personality formation is focused only on the biological energy that turns into psychosexual one, while the individual is allowed no opportunity to make an independent choice in life. S. Freud considered that the development of personality largely takes place up to five years.

S. Freud's position was carried further by E. Erikson and it was compensated by including specifics of Ego identification that determines the basic orientations with reference to own personality and own social environment. We need to add that personality formation does not end in adolescence, but continues throughout the entire life. The adolescence period after E. Erikson ranges from 12-13 and 19-20. In addition, each stage comprises individual parameters of personality development, which can have positive or negative meaning for the subject. E. Erikson determines crisis periods in each stage that coincide with the positions of L. Vygotsky. Such crisis periods are manifested by difficulties in determination, taking personality related decisions and, thus, they are a push for emergence of new formations within the personality system.

Age crises are important for the formation and modeling of values and value orientations of personality. The denial or reexamination of existing values privides an opportunity for changing and modeling of structural contents of value orien- 
tation: beliefs, attitudes, behaviors. A promoting factor for positive dynamics in value development is the social environment of personality, mainly for adolescent and youth age spans, while formation and development of value orientations according to social policies represents the educational environment.

The formation of values within the personality is impossible without social environment, without socialization process, which begins almost from the very birth. G. Andreeva believes that a number of public institutions participate in the socializing process, including family, school, mass media, state institutions, but one of the most fundamental roles belongs to family [3].

Russian scientist I. Kon defined socialization as the process of assimilating social experiences, acquiring norms, knowledge, values (Kon, 1989). D. Leontiev notes that the procedure for transforming values from the social environment into values of from the personality system necessarily implies a shift from values of a social group to values of the personality (which requires internalization, awareness) and the transition from an individual motivation structure (based on needs) towards a value-oriented structure (Leontiev, 2003). According to this scientist, the personality values represent "the relations preserved with the world generalized through the experience of the social group" (Leontiev, 2003).

L. Karpushina has investigated the structural changes in the personality values of adolescents and young people in universities according to the age criterion (Karpushina, Kaptsov, 2007, 2009). The results showed that in the 17-year-olds humanist values prevail, while in young people over 20 of age, pragmatic values gain priority. The researcher notes that for 17-year-old female subjects, it is important not just to interact with the social environment, but also to relate to recognition and esteem, which is specific for the given age. A dramatic change occurs in subjects 18-19 of age - the pragmatic values prevail considerably: prestige, achievement, material well-being, preservation of the identity. L. Karpushina found that in high school teenagers humanistic values such as self-devotion, spiritual satisfaction, creativity, social contacts, prevail more frequently. Such results are also identified in first year first tier students (Bachelor's). However, through socialization in the process of study in universities a re-evaluation of views, opinions occurs along with the axiological personality orientation. Starting at the age of 20 most young people express their identity crisis by diminishing the values in several areas of life and going back to the humanistic direction (Karpushina, Kaptsov, 2009). At the age of 20, the values of the personality pertain to latent variables with reverse signs, namely, the person makes use of non-conflictual, non-pretentious communication.

M.S. Kagan (1997) believes that personality development is associated with the "type of human activity structuring", while personality is described by five potentials: gnoseological, axiological, creative, communicative, and artistic. Values and 
value orientations are the most important part of a personality; they are a product of activity. With development of the axiological sphere of personality and value assimilation in the process of basic activities change, the personality gradually develops and the qualitative transformation of individual potential occurs.

Upon theoretical review of scientific data, D.V. Kashirsky identifies three stages in the development of values (D.V. Kashirsky, 2002, apud Karpushina, Kaptsov, 2009): 1) assimilation of norms and values (age 3-11); 2) formation of a system of values representations (age 11-17); 3) emergence of certain forms of values through which other development problems are solved (age 17-18 and older).

In the first stage, the formation of value orientations (including parental ones) takes place, which is focused on relationships between people. In the second stage, the basis for conscious behavior is laid and the general adolescence's tendency to form moral representations and social orientations emerges. In the third stage, the person acquires a stable system of values that guides him/her in choosing a direction in a certain social situation requiring resolution of a problem (D.V. Kashirsky, 2002, apud Karpushina, Kaptsov, 2009).

D.V. Kashirsky concludes that the process of the axiological sphere formation in children occurs at the age of 11-17, while at the age of 14 the crisis of "value reflection" takes place, which is favorable for formation of a value system of child's personality (D.V.Kashirsky, 2002, apud Karpushina, Kaptsov, 2009).

A. Davydova (2018) has carried out a longitudinal study to determine the laws of changes in the axiological sphere in high school pupils. The results of the experiment showed that the value spheres (profession, education, family, traditions, material well-being, etc.) and the personal values of the subjects undergoes a series of changes that are more pronounced in girls than in boys. The positive dynamics is found in the fields of self-determination and professional education, which can be explained by the specific characteristics of the given age and the social situation in which the development of individual occurs. However, visible changes have taken place at the level of the personal values in girls. The significance of indices such as the value of collectivity, the value of life and the value of material well-being has increased.

Russian scientists V.B. Salakhova, A.A. Oschepkov, N.V. Lipatova, P.V. Popov and I.V. Mkrtumov (2016) guided a theoretical-experimental study in addressing the concept of attitudes from the perspective of their relation with value orientations in young people and adolescents with self-aggressive behavior. In order to understand attitudes, the scientists have found a critical point in building the attitude exhibited by W. Thomas and F. Znaniecki and interpreted as "value" + "relationship to value". W. Thomas and F. Znaniecki defined an attitude as "psychological process, considering relations to the social world and taken primarily in relations to social values" (apud Salakhova, Oschepkov, Lipatova, Popov, Mkrtumov, 2016, p. 9019). 
A.G. Asmolov and M.A. Kovalchuk mentioned that the social attitude "is conditioned by the understanding of value as a social object that makes sense for the individual", or, otherwise, the social attitude describes the interrelation between the individual and the society in which the society is presented by social and individual value - through the relationship with this value (Asmolov and Kovalchuk, 1977; Salakhova, Oschepkov, Lipatova, Popov, Mkrtumov, 2016, p. 9019).

Based on the position described, the researchers were preoccupied with the study of interrelationship of the system of social attitudes and the system of values orienting of young people and adolescents as a basis for the regulation of behavior, which influences the manifestation of certain forms of behavior, including the self-aggressive one. Following the research the scientists obtained the following results: the values system of young people predisposed to self-aggressive behavior shows the higher rating of the values orientation of social power, which indicates the tendency of greater influence on people and events, on the authority, to which they must obey. At the same time, for young people who are not predisposed to self-aggressive behavior, the value given is related to the right to govern their own life through cooperation with the environment, having a higher social culture oriented towards reciprocity in relationships. However, the system of social attitudes in young people who are not predisposed to self-aggressive behavior shows a greater significance to achievement values, support of traditions, social culture and spirituality (Asmolov and Kovalchuk, 1977; Salakhova, Oschepkov, Lipatova, Popov, Mkrtumov, 2016).

A.Sisler believes that value orientations are essential in the development of adolescents' personal, social and cultural lives, having a significant impact on their relationships, identity, well-being and life prospects. A cross-cultural study (Kasser, 2011; Schwartz, 1994; Sisler, 2016, p. 13) made for the conclusion that when value sets are extrinsically linked or oriented toward external goals, they are associated with increased stress and inadequacy, lower levels of empathy and attitudes and harmful intergroup behavior and harmful lifestyles. In contrast, according to Grouzet, 2005; Kasser 2002; Maio, Pakizeh, Cheung, \& Rees, 2009, when values are self-transcendent or intrinsically goal-oriented, that is, oriented towards autonomy and agentic growth, close affili,ate relationships, belonging to widespread community and harmony, they are largely associated with greater life satisfaction, well-being and prosociality (apud Sisler, 2016).

Kasser (2011) mentions that value orientations predict the current and potential well-being of children at the national level when they are aligned with egalitarian and harmonious relationships, according to this set of intrinsic values, in contrast to hierarchical and dominant value orientations (Kasser, 2011; Sisler, 2016). Studies by Konrath, O’Brien, \& Hsing (2010), Twenge, Konrath, Foster, Campbell 
and Bushman (2008), Uhls \& Greenfield (2012), Uhls, Zgourou and Greenfield (2012) on youth values show agrowing preference for externally oriented sets of values and coterminous (boderline) constructions such as materialistic and narcissistic tendencies, including efforts to gain fame and aggressive competition (apud Sisler, 2016).

Based on review of literature, A. Sisler highlighted the main ideas regarding the process of building structural components of value orientations, finding that the values serve as interactive nodes for emotions and preferences influenced by the socio-cultural aspects, as well as attitudes, beliefs and behaviors which are generated by such values (Sisler, 2016). However, research shows that, despite the centrality of the adolescents' value orientations highlighted in the individual development and their importance for the subsequent results, a lack of systemically based ecological dynamic knowledge integrated from multiple contexts prevails.

For study of relationship between value orientations and motivation for learning, a research was carried out which found a significant positive relationship between value orientations and motivation for learning. The components of value orientations of a person that are in a positive relation with learning motivation variables reflect, to a certain extent, the socio-economic environment in which they live, the level of well-being experienced previously, the life experience of teachers, which is confirmed by a tendency towards self-achievement, self-expression, autonomy, as well as towards better health condition (including satisfaction of lower needs), financial welfare, etc.

A significant positive relationship was found between: achievement value and cognitive motivation; the value of advancement and the regulation of values (from the motivation system for learning) that influence the formation of personal value structure in learning activity; autonomy and motivation for achievement; balance and emotional adjustment; challenge and reasons for emotional experiences; challenge and volitional regulation; competitiveness and the reasons for the emotional experiences; financial security and the reasons for emotional experiences which shows that the personality chooses a direction in activity that will ensure obtaining of positive emotions; independence and emotional regulation; status and the regulation of values which speaks of a high level of value development (Antoci, 2013).

\section{The experimental study}

The initiated research aims at determining the hierarchical and dominant value orientations in current adolescents and young people. In addition, the present study is focused on determining the specifics of the value orientations dynamic of ado- 
lescents and young people during the period of personal and professional training. According to stated research aim, 200 persons aged 13 to 14 and 25 to 30 years were involved. In order to study value orientations, the test of Identification of Value Orientations (IOV) was applied (2008).

The study to ascertain the value orientations was undertaken in 2015 with young people from universities and it was repeated in 2019 involving pre-adolescents, adolescents and young people. Various types of theoretical and experimental research has led to the idea of investigating the value orientations from the preadolescent age to the age of youth, which widened the range of representatives in the experimental group in 2019.

The results obtained upon conducting the experimental study in 2019 in dynamics of value orientations during the adolescent and youth periods are shown in figure no 1 . The data of the preadolescent and adolescent age persons are connected with the left axis of the diagram, while results for youth are shown in the right axis of the diagram.

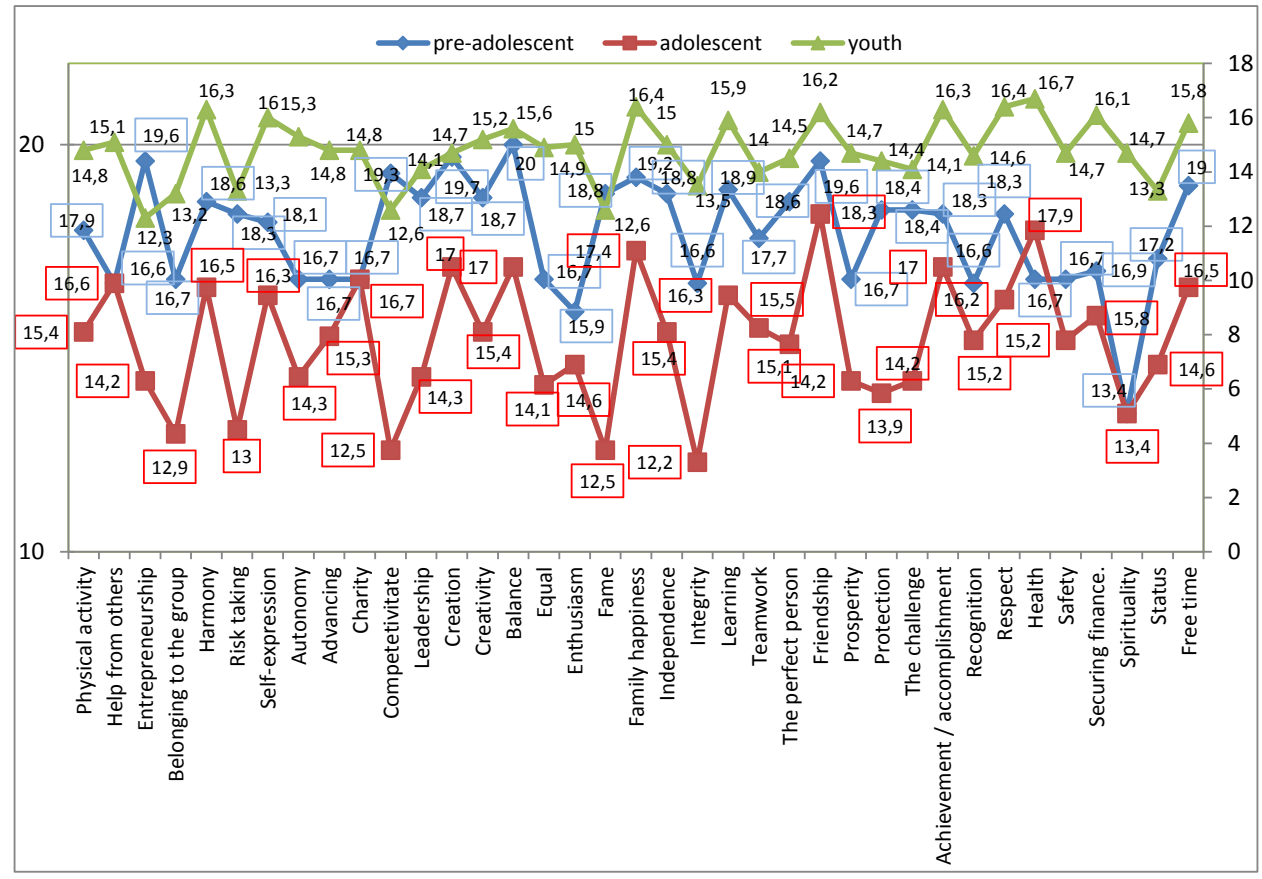

Figure no 1. Indices of the value orientations of preteens, adolescents and young people investigated in 2019 using the IOV test (GOTC, 2008), (points) 
The analysis of the figure allows to ascertain that the dominant value orientations for pre-adolescents are: balance (20p.), that denotes that the subjects try to maintain a balance in the allocation of time and energy to work and personal life; creation (19.7p.) which shows conception or foundation of a thing or an idea in the course of activities carried out; entrepreneurship and friendship (19.6p.) have the same index which can be explained by the age specifics of the subjects, who try to organize or initiate a project, a business together with friends, which brings about affection, gratitude and a state of wellbeing, joy and mirth; competitiveness (19.3) shows training in activities whereby results are frequently compared with those of others; family happiness (19.2p.) denotes focus on relationship with the family, on time and attention given to siblings, parents or relatives; free time (19p.) expresses the importance of conducting recreational activities by subjects; learning (18.9p.) shows the need of acquiring knowledge and satisfying the curiosity of contemporary preteens.

Value orientations which were mentioned less frequently by modern pre-adolescents were: spirituality (13.4p.), which cannot be specific for person through ideas, feelings, culture as expressed in actions and behaviors and shows less the intelligence of the human being; the enthusiasm (15.9p.) is explained by the fact that the subjects are not very involved in new and dynamic experiences that can represent a diversity, a possible risk; the recognition, integrity, help of others (16.6p.), being equal in score, shows that pre-adolescents do not really want to be appreciated by others, do not adhere firmly to a moral code, do not offer support and help to colleagues, peers.

The analysis of indices obtained from the evaluation of the results of the hierarchy of value orientation by adolescents allows to notice changes in the eight dominant value orientations. Thus, in the foreground we highlight the friendship (18.3), which, being specific to given age, highlights the importance of stable and affectionate friends, satisfaction and well-being, joy and mirth associated with the former. Then, health follows (17.9) whereby we find use of optimal functioning of the body, mind and spirit by adolescents. We find happiness of the family (17.4p.) in the dominant value orientations. That is present at all ages which is a positive fact for our country. The following three value orientations accumulated $17 \mathrm{p}$ each: achievement/fulfillment, balance, creation. The accomplishment/fulfillment speaks about involvement of adolescents in various actions in order to obtain significant results, focusing on successful fulfillment of tasks and projects. The balance highlighted by the subjects shows the use of balance between the workplace and personal life and, accordingly, distribution of time and energy. Creation attests to the desire, importance of founding a thing or an idea. The existence in value orientations of the adolescents of charity (16.7p.) shall be appreciated, along with help 
to others (16.6p.), which points out willingness for and participation in building a better world by subjects.

The value orientations that show the lowest score are: integrity (12.2p.); fame and competitiveness (12.5p.); belonging to a group (12.9p.); risk taking (13.0p.); spirituality (13.4p.). How can we interpretthe data obtained? We can firmly state that adolescents are still in the determination of an ethical code, worthy to follow, they do not aim at maximum expression, at involvement in activities whereby results are compared to those of their peers. As compared to pre-adolescents, the adolescents no longer want to be part of a group just to make their own contribution. However,, subjects are less likely to take risks, to face unknown and dangerous challenges and demands. The spirituality shown by preteens is also specific to adolescents.

Data analysis and hierarchical distribution of value orientations in young people allows to highlight the following dominant variables: Health (16.7p.), Family happiness (16.4p.), Respect (16.4p.), Achievement / fulfillment (16.3p.), Harmony (16.3p.), Friendship (16.2p.), Financial security (16.1p.), Self-expression (16p.). Comparative analysis of data on adolescent subjects allows to find the repetition of some, but also the appearance of others, for example, the value orientation Respect shows valorisation of being treated with esteem and fairness; achievement / fulfillment shows importance of obtaining significant results, successfully completing tasks. We mention the occurrence among the dominant values of Harmony, which points to the need for inner tranquility and serenity. One variable that has not been highlighted by subjects of previous ages is Financial security, which confirms that salary or benefits are satisfactory and predictable.

In addition to the dominant values, we may wention the less prior ones: Entrepreneurship (12.3p.), Fame and competitiveness of 12.6p., Group membership (13.2p.), Status and risk taking (13.3p.). Maintaining and interpreting positions regarding fame, competitiveness and belonging to young people are typical of adolescent subjects. The least appreciated variable refers to belonging to agroup which is explained by the fact that the emotionally young people do not really want to be part of a group in which to intervene with their own contribution in achieving some goals, results, which also explains the score of risk and status variable, which shows a prestigious position or rank as a lower preference, at the lower level in the hierarchy.

At the same time with the determination of the dynamics in the dominance and the hierarchy of the value orientations at the pre-adolescent, adolescent and youth ages, the interest in establishing the dynamics of the changes in the time periods in young people was presented. Therefore, we present the data of young people diagnosed in 2015 and 2019 (figure no 2). The results of the youth of 2015 show 
the accumulated score by ranking the value orientations; The indexes of the value orientations of the young people from 2019 constitute the accumulated score according to their importance for the subject.

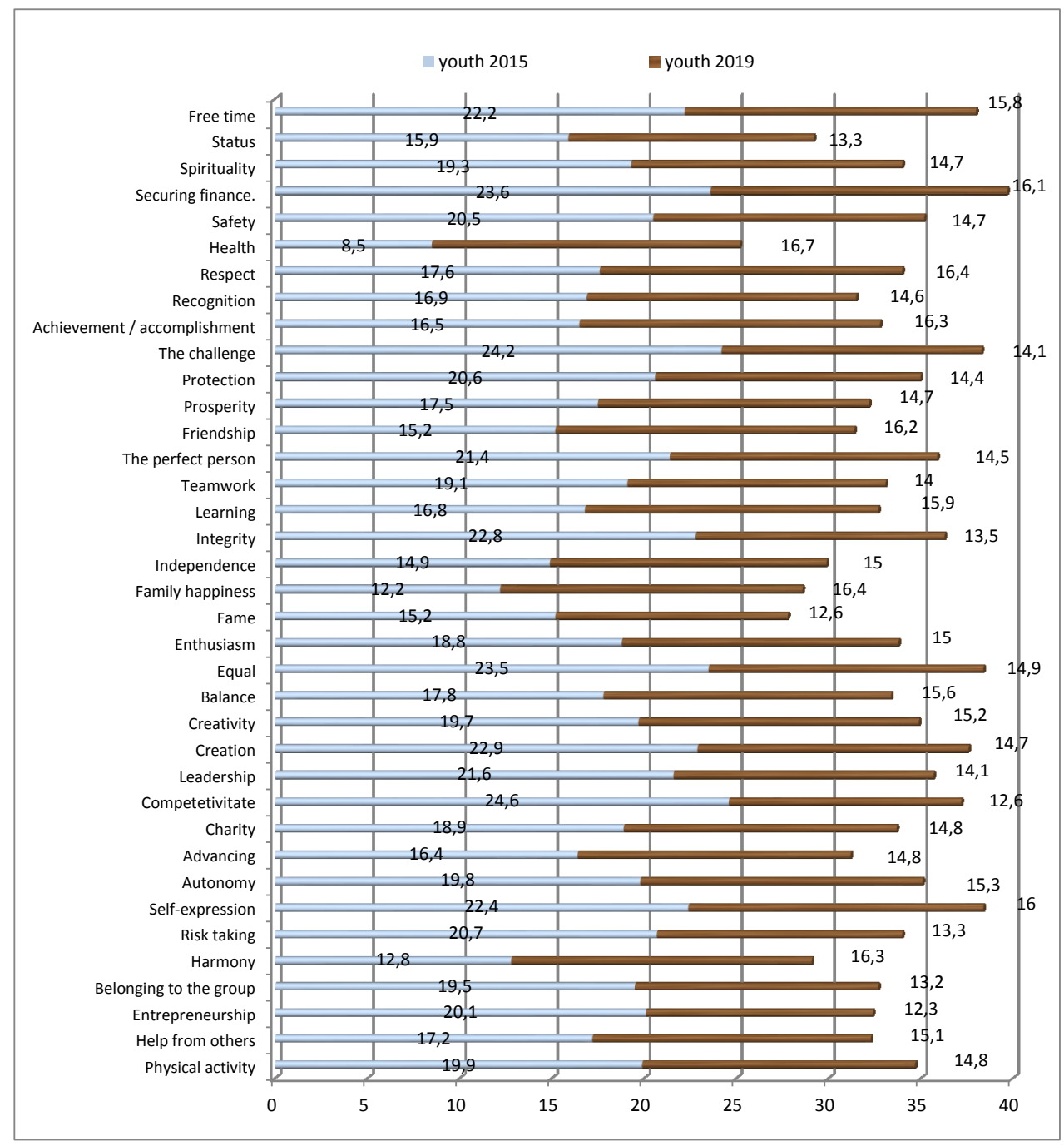

Figure no 2. Indices of value orientations in young people studied in 2015 and 2019 using the IOV test (GOTC, 2008) (points)

The data analysis allows to state the presence of dominant value orientations identical to the young people who participated in the research in 2015 and 2019; these are: Health (8.5p and 16.7p), Family happiness (12.2p and 16, 4p.), Friendship 
(15.2p. and 16.2p.), Harmony (12.8p. and 16.3p.). Among the young people who participated in the 2015 survey, other dominant variables are found: Independence (14.9p.), fame (15.2p.), status (15.9p.), advancement (16.4p.). In young people who participated in the 2019 survey, we highlight: respect (16.4p.), achievement/fulfillment (16.3), financial security (16.1p.) and self-expression (16.0p.).

Among the less prior variables for young people in 2015 are: competitiveness (24.6p.), challenge (24.2p.), financial security (23.6p.), equality (23.5p.), creation (22.9p.), integrity (22.8p.), self-expression (22.4p.). In the subjects of youth age involved in research in 2019, we highlight the following value orientations less appreciated by respondents: entrepreneurship (12.3p.), fame (12.6p.), competitiveness (12.6p.), belonging to a group (13.2p. ), status (13.3p.), risk taking (13.3p.), Integrity (13.5p.). From the ones highlighted, we emphasize the less important identical variables for young people: competitiveness, integrity; in variables - the results differ. The major difference is the focus of young contemporaries on financial security, while the 2015 subjects did not deem it important; in the subjects of 2015, the variable of fame was among the dominant ones, while in the young people of 2019 study, fame is deemed as less valuable.

\section{Conclusions}

The study of values from the perspective of structure, age, gender, family social environment in adolescents and young people is not new in education sciences. Due to continuous change in society, which are currently of huge significance, the value orientations are also continuously changings, thus the need for their study. According to the data in scientific literature, we can see that the structure of value orientations in the personality of adolescents and young people is made up of the latent variables, their composition and correlation depending on age, education, culture, social environment.

Upon analysis of various scientific approaches regarding specifics of developing value orientations in adolescents and young people, we can conclude that the process of value formation begins gradually and extends throughout the entire school period. The value orientations start with a preliminary outline at pre-adolescent age, continue in adolescence and take a definitive outline in youth. The literature in the field of pedagogy, psychology, philosophy, sociology allows to find various studies carried out in order to establish the way to prioritise values, the impact of factors on the process of value establishment, the ratio of values with a wide spectrum of elements within personality sphere, the modality for value establishment, etc. Upto-date many questions remain unanswered in a truly scientific manner, including 
those related to the methodology of value formation, research of the constituent elements of the value orientations.

The study of the value orientations of young people allows us to ascertain the relation of the variables determined by the contextual reality of individual formation. The positions shown reflect to some extent the particularities of age, the socio-economic environment in which young people live, learn, work, previously experienced levels of welfare in the past and in the present, their life experience, etc. The results of the research show the concerns of the young people directed to achievement and fulfillment, harmony and respect, family happiness, friendship, and last but not least, learning is nominated, and, surely, today's young people think about security, the financial prosperity that largely ensures the future of the country and its citizens.

Thus, the continuous study of the value orientations from various perspectives and of specifics of their development in children will allow to determine the specific ways of transmission, assimilation, appropriation of cultural value systems and of personal value formation in people.

\section{References}

Antoci D. (2013). Relația dintre orientările valorice și motivația pentru învățare la viitoarele cadre didactice. In: Matrrialele Conferinței științifico-practice Formarea competenței de invățare la elevi. Chișinău: Universitatea de Stat din Tiraspol, Liceul Teoretic „ORIZONT”, p. 12-19.

Ghid de orientare profesională a tinerilor şi planificare a carierei. (2008). Suport de curs. Centrul de Informare şi Documentare privind Drepturile Copilului. Chişinău: CIDDC, 115p.

Salakhova V.B., Oschepkov A.A., Lipatova N.V., Popov P.V., Mkrtumov I.V. (2016). Features of social attitudes and value orientations of youths and adolescents prone to auto-aggressive behaviour. International Journal of Environmental \& Science Education. vol. 11, no. 16, 9017-9025, URL: https://files.eric. ed.gov/fulltext/EJ1118757.pdf [accessed 30.08.2019].

Sisler A. (2016). Adolescents' value orientation development in light of socio-cultural influences. Genehmigte Dissertation. Berlin, URL: https://depositonce.tu-berlin.de/bitstream/11303/6105/4/sisler_aiden.pdf [accessed 05.09.2019].

Андреева Г. (2000). Психология соииального познания: учебное пособие для студентов вузов. Москва: Аспект Пресс, 288c.

Давыдова А. (2018). Динамика личностных ценностей учеников старших классов. Вестник Самарской гуманитарной академии. Серия «Психология». № 1(23), с. 61-69. 
Каган М.С. (1997). Философская теория ценности. СПб: ТОО ТК «Петрополис», 205c.

Карпушина Л.В., Капцов А.В. (2007). Структура личностных ценностей. // Вестник Самарской гуманитарной академии. Серия «Психология». № 1, cc. 61-67.

Карпушина Л.В., Капцов А.В. (2009). Психология иенностей российской молодежи: монография. Самара: «Изд-во СНЦ РАН», 252с.

Кон И. (1989). Психология ранней юности. Москва: Просвещение, 255c.

Леонтьев Д.А. (2003). Психология смысла: природа, строение и динамика смысловой реальности. Москва: Смысл, 487c.

\section{System wartości nastolatków i młodych ludzi: przegląd i obecna sytuacja}

\section{Streszczenie}

W niniejszym artykule dokonano przeglądu szeregu podejść teoretycznych i naukowych w odniesieniu do specyfiki kształtowania i manifestacji systemu wartości wśród nastolatków i młodych ludzi. Badanie orientacji wartości zostało przeprowadzone poprzez przegląd stanowisk naukowych dotyczących opisu procesu kształtowania się wartości w ontogenezie, potrzeby implikacji w różnych działaniach ludzkich dla rozwoju orientacji wartości w dzieciństwie, wpływu szerokiego spektrum czynników kształtujących orientacje wartości, korelacji wartości z elementami strukturalnymi osobowości itp. Eksperymentalne studium, rozpoczęte w 2015 roku i powtórzone w 2019 roku, odzwierciedla specyfikę dynamiki orientacji wartości u nastolatków i młodych ludzi w ramach systemu edukacji przeduczelnianej i uniwersyteckiej. Treść pokazuje aktualny charakter badań i zarysowuje perspektywy dalszych badań w tym obszarze.

Słowa kluczowe: wartość, system wartości, nastolatki, młodzież. 